\title{
Recognition of Adulteration in Milk: A Review
}

\author{
Iqra Bano $^{1 *}$, Hira Sajjad ${ }^{2}$ and Mohammed Zeb khan ${ }^{3}$ \\ ${ }^{1}$ Department Veterinary Physiology \& Biochemistry SBBUVAS Sakrand, 67210 Pakistan
}

${ }^{2}$ Key Laboratory of Agricultural Animal Genetics, Education Ministry of China, Huazhong Agricultural University, People’s Republic of China

${ }^{3}$ Department of Preventive Veterinary medicine, Northeast Agriculture University Harbin China

Submission: November 28, 2018; Published: January 10, 2019

*Corresponding author: Iqra Bano, Department Veterinary Physiology \& Biochemistry SBBUVAS Sakrand, 67210 Pakistan, Pakistan

\begin{abstract}
The food debasement is a worldwide problem and emerging nations are at sophisticated risk related with it because to deficiency of specialist care and strategies. Though, it is the greatest common issue that has been unnoticed in numerous countries. Tactlessly, in distinction to common certainty, milk additives can cause various life-threatening issues leading to death of consumers. The current paper grants a comprehensive assessment of common milk alloys as well as various means to perceive the adulterants. Currently milk is being mixed in more sophisticated behaviours that demands proper research for the detection of the adulterants.
\end{abstract}

Keywords: Milk; Adulteration; Dairy

Abbreviations: FSA: Food and Drug Administration; SCC: Somatic Cell Count; CE: Capillary Electrophoresis; SIA: Sequential Injection Analysis

\section{Introduction}

Naturally, milk has a high nutritious worth as it is a virtuous basis of excellence vitamins, fats, proteins, carbohydrates, and mineral deposits [1]. It is effortlessly consumable and thus it is willingly absorbed particularly significant for toddlers, milching animals, progenies and aged animals. Milk proteins similarly provide amino acids desirable for the appropriate development of grownups and children [2]. Though, if impure, it leads an economic burden on the handler and becomes dangerous to customers by becoming inferior in quality. Like, people sensitive to cows' milk can suffer severely if they consume ovine or caprine milk tainted by means of bovine milk or else whey [3]. The adulteration of milk is a performance of deliberately dropping its superiority, accessible for sale either by addition of poorer ingredients or by elimination of various appreciated ingredient. It may be either intentional to earn extra money by the addition of extraneous water, non-dairy melamine, proteins, animal fat, urea, re-formed milk, artificial milk or possibly will be mixed with some natural means, like the natural entry of antibiotics into the milk from cattle treated for mastitis, or dust particles or other extraneous objects that might have entered the milk throughout handing out.

Maximum of the times, the debasement of milk is deliberate to make more profit, but then occasionally it may be due to the absence of appropriate perceiving technology in addition misperception due to drug usage practices [4]. Some studies have revealed that following the treatment of mastitis the milking animal shown traces of antibiotic deposits in milk; also in lack of appropriate guideline about the lactation period and improper handling of teats frequently lactation is done in incorrect time with contaminated hands leading antimicrobial remainders in milk (if milking done early) or surplus of milk (if lactation is performed late) [5]. Occasionally ordinary milk is mixed with low cost constituents like whey, water etc. and is recognized as 'financial adulteration.' This is a very common practice from the milk traders to enhance water or else 'fluid-whey' with milk [6] furthermore the watery milk decreases its nutritive worth, and polluted water grounds thoughtful health issues. Accumulation of water deviates specific gravity of the milk and its usual appearance gets demolished. To perceive water in milk typically scientific device used is called lactometer by which the alteration in specific gravity is observed [7]. But then again to reimburse the specific gravity, diverse categories of salt besides sugar12 are used [8]. Rarely to hold it colour a minor quantity of dye is also added [9].

The Maltodextrin are commonly used in dairy diets to improve flavour and decrease the price of the foodstuffs [10]. The additional adulterant commonly used is liquid whey (obtained subsequently creation of cheese by milk). Some manufacturers, for better profit, utilise low-priced muriatic acid to make the whey which grounds solemn fitness issues and require discovery of adulterated milk through whey. The distinctiveness of this debasement is that it is not changing the lactose contented of the milk but then rises its acidity. To reduce its acidity a minor quantity of alkaline solution of sodium hydroxide is added [11]. The elimination of the cream or marketing of scanned 
or moderately skimmed milk as complete milk is likewise one arrangement of milk debasement. This paper attempts to investigate various milk adulterants and their health dangers.

\section{Milk Adulterant and its Detection}

The observation of milk excellence is significant for diet protection, as well as for course of the production of dairy products. There are numerous sophisticated approaches such as chromatography and spectroscopy etc. which are used to perceive the milk quality. Moreover, there are many other different bio detecting methods used for recognition of milk adulteration. Like a biosensor which is an exploratory device that in close interaction by a transducer adapts a biological indication into an assessable electrical gesture. The biological constitutes of this device are some enzymes, antibodies, tissues, and receptors. Numerous biosensors are combined by the electrical devices to perceive the milk adulteration. Repeatedly lactose attentiveness acts as an elementary indicator for the assessment of milk superiority and the discovery of irregularities [12].

\section{The antibiotics in milk}

To treat animals against infections like mastitis $80 \%$ of dairy herds relay on antibiotic therapy. These antibiotics by means of antimicrobial deposits are present in profusion with in milk [13]. Occasionally these mixtures are correspondingly added to rise the shelf life of milk products [14]. The common antimicrobial medications are tetracyclines, sulphonamides, and nitrofurans antimicrobial remainder [15] in addition to some beta-lactam drugs like penicillin-G, amoxicillin, cloxacillin, dicloxacillin, cefuroxime and cefoperazone [16]. The Pasteurization and other methods of temperature dealing are very effective for pathogens but have imperfect belongings on drug remainders [5]. The USA food and drug administration (FDA) have investigated around 80 drug remainders in livestock derived human diet [17]. The presence of antimicrobial components in milk can root latent dangers to the customer. Residues of medications in milk lead serious health threats like allergic responses, [18] upsurge in the amount of antibiotic resistance causes damage to the abdominal flora [19] and some may possess carcinogenic belongings. Furthermore, it may also cause tissue damage [20]. It restricts in the fermentation of bacterium and cause loss of fermented products. The most viable method to detect antibiotic residue in milk is named as Somatic cell count (SCC) [21]. Moreover, the antimicrobial deposit can be spotted by giving with a biochemical reagent [22].

\section{Addition of Colour in Milk}

Numerous food colorants are correspondingly added which have dangerous consequence on health. The investigative technique named as capillary electrophoresis (CE) is done for the parting of diet colorants. CE method stretches a minor sample volume and visual pathway. The finding limit is disappointing [9].

\section{Use of Preservatives}

The growth of microorganism causes destruction in its structural components and make it un healthy. Generally, the milk comprising bacteria [23] changes lactose into lactic acid. which in turn fluctuates the electrical restriction of the milk. The conductivity is an easy parameter to perceive bacteria, but it is powerfully influenced by fat percentage of the milk and mainly used to diagnose the mastitis [24]. Moreover, some pesticides are likewise mixed with milk to destroy the germs existing in milk. and to fight its additional development or in other words it acts as a preservative. The pesticides existing in milk can be perceived by method known as mass spectrometry [25]. According to some research Occasionally hydrogen peroxide $\left(\mathrm{H}_{2} \mathrm{O}_{2}\right)$ is also used to preserve milk and E-Tongue technique is used for the detection of $\mathrm{H}_{2} \mathrm{O}_{2}$ and fat percentage of the milk [26]. Beside this formalin and Boric acid are regarded as oldest adulterants agents mixed with milk as preservative [27]. It progresses the abdominal discomfort, diarrhea, nausea and further poison associated warning signs. The Rosalic acid test is a very common test to perceive formalin in milk [28].

\section{Mixing of Urea in Milk}

The urea is a very common milk adulterant used to surge its shelf life. Beside this the urea is also used for preparation of artificial milk. The urea components in milk could also rise due to instable nourishing of cows [29]. Unstable urea components in milk causes fertility of dairy cows. Moreover, it is also used for heat constancy [30]. the Health threats related urea are ulcers, acidity, stomach-ache, and tumours. The urea is injurious to kidneys. Liver, heart and many other visceral organs particularly it damages kidneys as they eliminate it from the body [31]. This requires the importance of recognition of urea in milk. The procedures for assessment of urea within milk are consequential from the response of urea by p-dimethyle amino benzaldehyde or else diacetyl monoxime and estimated by ion discriminating electrode [32]. The urea is also perceived by another method known as calorimetric technique [33]. It is also detected by the physical appearance and absorption possess of the amide tie of urea in infrared section [34].

\section{Addition of Chlorine in millk}

Chlorine is mixed with milk to recompense the thickness of the thinned milk subsequently accumulation of liquid. The inflammation of udder in cow also increases the chlorine amount within the milk. The chlorinated milk can root obstruction in blood vessel and progress heart issues [8]. Furthermore, for detection of chlorine in milk the procedure named as sequential injection analysis [SIA] based on titration with silvery cation is done. Moreover, the chlorine recognition in milk is likewise done by titration with potentiometric finding [35].

\section{Addition of Neutralizers in milk}

The neutralizers as sodium carbonate, hydrated lime, sodium bicarbonate or sodium hydroxide, are mixed with milk which are 
usually banned. The sodium hydroxide is often used in artificial milk to deactivate the acidic consequence [7]. The consumers develop cancer due to the ingestion of milk polluted with sodium hydroxide. The Unreal milk is a usual issue which is organized by addition of some refined oils, caustic soda, and some common cleansing agent. It is shown by some studies that the caustic soda which comprises sodium, turns as slow venom for the heart patients. Because the caustic soda denies the physique from exploiting lysine, an indispensable amino acid present in milk, which is essential for rising babies. Such type of synthetic milk is very destructive for all consumers specially for expecting women [36].

\section{Conclusion}

Though the financial improvement is one of the chief motives for milk debasement, insufficient source this is more common in the emerging and under established states because of deficiency of satisfactory intensive care and law implementation. The Current common recognition methods are not continuously suitable and reachable in these nations making it hard to discourse the varied behaviours of fake sullying in milk. This noises for mutual exertions from systematic societies and the supervisory authorities by proper development, application and broadcasting of improved methods for the discovery of milk debasement. Furthermore, responsiveness and access to evidence can lead dynamic role in these areas to repress this issue. Some of these informal finding methods at the customer level can bring this issue conclusion for the sufferers, counting lots of progenies in the unindustrialized states.

\section{References}

1. Neumann C, Harris DM, Rogers LM (2002) Contribution of animal source foods in improving diet quality and function in children in the developing world. Nutrition Research, 22(1): 193-220.

2. Afzal A, Mahmood MS, Hussain I, Akhtar M (2011) Adulteration and microbiological quality of milk (a review). Pakistan Journal of Nutrition, 10(12): 1195-1202.

3. Pesic MB, Barac MB, Vrvic MM, Ristic NM, Macej OD, et al. (2011) The distributions of major whey proteins in acid wheys obtained from caprine/bovine and ovine/bovine milk mixtures. International Dairy Journal, 21(10): 831-838.

4. Payne M, Bruhn CM, Reed B, Scearce A, O’Donnell J (1999) On-farm quality assurance programs: a survey of producer and industry leader opinions. Journal of Dairy Science, 82(10): 2224-2230.

5. Tan X, Jiang YW, Huang YJ, Hu SH (2009) Persistence of gentamicin residues in milk after the intramammary treatment of lactating cows for mastitis. Journal of Zhejiang University-Science B 10(4): 280-284.

6. Galloway JA (2000) Great fare of London. The Lancet 355(9200): 323324 .

7. Das S, Goswami B, Biswas K (2016) Milk adulteration and detection: a review. Sensor Letters, 14(1): 4-18.

8. Lima MR, Fernandes SM, Rangel AO (2004) Sequential injection titration of chloride in milk with potentiometric detection. Food control 15(8): 609-613.

9. Huang HY, Shih YC, Chen YC (2002) Determining eight colorants in milk beverages by capillary electrophoresis. Journal of chromatography A, 959(1): 317-325.
10. Borin A, Ferrao MF, Mello C, Maretto DA, Poppi RJ (2006) Leastsquares support vector machines and near infrared spectroscopy for quantification of common adulterants in powdered milk. Analytica chimica acta 579(1): 25-32.

11. Kasemsumran S, Thanapase W, Kiatsoonthon A (2007) Feasibility of near-infrared spectroscopy to detect and to quantify adulterants in cow milk. Analytical Sciences, 23(7): 907-910.

12. Conzuelo F, Gamella M, Campuzano S, Ruiz MA, Reviejo AJ, et al. (2010) An integrated amperometric biosensor for the determination of lactose in milk and dairy products. Journal of agricultural and food chemistry 58(12): 7141-7148.

13. Gustavsson E, Bjurling P, Degelaen J, and Sternesjö Å (2002) Analysis of $\beta$-lactam antibiotics using a microbial receptor protein-based biosensor assay. Food and agricultural immunology 14(2): 121-131.

14. Ndungu TW, Muliro PS, Omwamba M, Oosterwijk G, Jansen A (2016) Quality control of raw milk in the smallholder collection and bulking enterprises in Nakuru and Nyandarua Counties, Kenya. African Journal of Food Science 10(5): 70-78.

15. Alomirah H, AL-Mazeedi HANI, AL-Zenki Sameer, AL-Aati Tareq, AlOtaibi Jamla, et al. (2007) Prevalence of antimicrobial residues in milk and dairy products in the state of Kuwait. Journal of Food Quality 30(5): 745-763.

16. Sierra D, Sánchez A, Contreras A, Luengo C, Corrales JC, et al. (2009) Detection limits of four antimicrobial residue screening tests for $\beta$-lactams in goat's milk. Journal of dairy science 92(8): 3585-3591.

17. Ghidini S, Zanardi E, Varisco G, Chizzolini R (2003) Residues of $\beta$-lactam antibiotics in bovine milk: confirmatory analysis by liquid chromatography tandem mass spectrometry after microbial assay screening. Food Additives \& Contaminants 20(6): 528-534.

18. Holstege DM, Puschner B, Whitehead G, Galey FD (2002) Screening and mass spectral confirmation of $\beta$-lactam antibiotic residues in milk using LC-MS/MS. Journal of agricultural and food chemistry 50(2): 406-411.

19. Molina A, Molina MP, Althaus RL, Gallego L (2003) Residue persistence in sheep milk following antibiotic therapy. The Veterinary Journal 165(1): 84-89.

20. Schultz JC, Adamson JS, Workman WW, Norman TD (1963) Fatal liver disease after intravenous administration of tetracycline in high dosage. N Engl J Med 269(19): 999-1004.

21. Ruegg PL, Tabone TJ (2000) The relationship between antibiotic residue violations and somatic cell counts in Wisconsin dairy herds. Journal of dairy science 83(12): 2805-2809.

22. Kneebone J, Tsang PCW, Townson DH (2010) Short communication: Rapid antibiotic screening tests detect antibiotic residues in powdered milk products. Journal of dairy science 93(9): 3961-3964.

23. Qian JY, Chen W, Zhang WM, Zhang H (2009) Adulteration identification of some fungal polysaccharides with SEM, XRD, IR and optical rotation: A primary approach. Carbohydrate Polymers 78(3): 620-625.

24. Lake JR, Hillerton JE, Ambler B, Wheeler HC (1992) Trials of a novel mastitis sensor on experimentally infected cows. Journal of dairy Research 59(1): 11-19.

25. Careri M, Bianchi F, Corradini C (2002) Recent advances in the application of mass spectrometry in food-related analysis. Journal of Chromatography A, 970(1): 3-64.

26. Paixão TR, Bertotti M (2009) Fabrication of disposable voltammetric electronic tongues by using Prussian Blue films electrodeposited onto CD-R gold surfaces and recognition of milk adulteration. Sensors and Actuators B: Chemical, 137(1): 266-273.

27. Hewedy MM, Smith CJ (1989) Detection of soy milk in pasteurized bovine milk. Food Hydrocolloids, 3(5): 399-405. 
28. Harding F (1995) Adulteration of milk. In Milk quality pp. 60-74.

29. Trivedi UB, Lakshminarayana D, Kothari IL, Patel NG, Kapse HN, et al. (2009) Potentiometric biosensor for urea determination in milk. Sensors and Actuators B: Chemical, 140(1): 260-266.

30. Paradkar MM, Singhal RS, Kulkarni PR (2000) An approach to the detection of synthetic milk in dairy milk: 1 . Detection of urea. International Journal of Dairy Technology 53(3): 87-91.

31. Kandpal SD, Srivastava AK, Negi KS (2012) Estimation of quality of raw milk (open \& branded) by milk adulteration testing kit. Indian Journal of Community Health, 24(3): 188-192.

32. Sharma R, Rajput YS, Kaur S, Tomar SK (2008) A method for estimation of urea using ammonia electrode and its applicability to milk samples Journal of dairy research 75(4): 466-470.
33. Bhavadasan MK (2014) A simple colorimetric method for the determination of urea in milk. 35: 3.

34. Hansen PW (1998) Urea determination in milk using Fourier transform infrared spectroscopy and multivariate calibration. Milchwissenschaft.

35. Ramsing AU, Růžička J, Hansen EH (1981) The principles and theory of high-speed titrations by flow injection analysis. Analytica Chimica Acta, 129: 1-17.

36. Jha SN, Matsuoka T (2004) Detection of adulterants in milk using near infrared spectroscopy. Journal of food science and Technology-Mysore, 41(3): 313-316.

\section{Your next submission with Juniper Publishers will reach you the below assets}

- Quality Editorial service

- Swift Peer Review

- Reprints availability

- E-prints Service

- Manuscript Podcast for convenient understanding

- Global attainment for your research

- Manuscript accessibility in different formats ( Pdf, E-pub, Full Text, Audio)

- Unceasing customer service

Track the below URL for one-step submission https://juniperpublishers.com/online-submission.php 